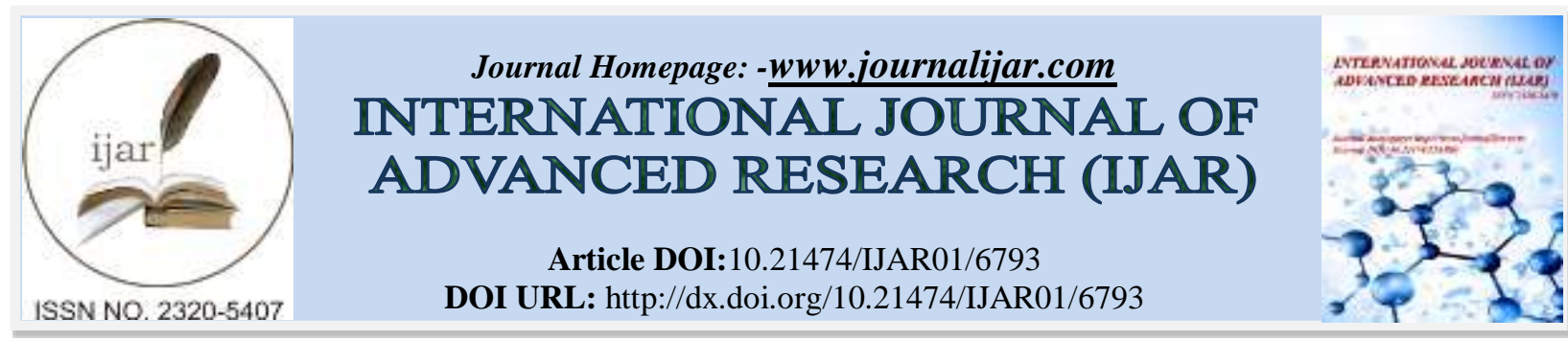

RESEARCH ARTICLE

\title{
DYNAMIC CHANGES IN THE UPPER RESPIRATORY TRACT MICROFLORA OF THE BLACK SEA AND PACIFIC BOTTLENOSE DOLPHINS IN NOOGENIC HABITAT: POSSIBLE INFLUENCE OF ENVIROMENTAL CONDITIONS.
}

\author{
T. Tserodze ${ }^{1,2}$, D. Jgenti ${ }^{1}$, M. Mgeladze ${ }^{1}$, I. Gambashidze ${ }^{1}$, N. Chkheidze ${ }^{1}$, E. Jaiani ${ }^{3}$, E. Didebulidze ${ }^{3}$, \\ N. Janelidze ${ }^{3}$, R. Goradze ${ }^{2}$ and M. Tediashvili ${ }^{3}$. \\ 1. The Black Sea Flora and Fauna Research Center, Batumi, Georgia. \\ 2. Rustaveli Batumi State University, Batumi, Georgia. \\ 3. G. Eliava Institute of Bacteriophages,Microbiology and Virology, Tbilisi, Georgia.
}

\section{Manuscript Info}

\section{Manuscript History}

Received: 20 January 2018

Final Accepted: 22 February 2018

Published: March 2018

Keywords:-

Marine mammals, noogenic condition, microflora, Aeromonas, S. Aureus, S.epidermidis.

\section{Abstract}

Infectious diseases of upper respiratory tract (URT) represent serious problem for marine mammals adapted to noogenic conditions. Anthropogenic contamination of pool water is considered as an important source of potentially harmful bacteria. The changes in climatic conditions, nutrition and stress of animals living in an artificial environment can result in bacterial overgrowth and disease development with possible spread in the community. Treatment of already advanced disease is complicated and positive outcome largely depends on timely diagnostics. Regular control of behavioral and nutritional changes of marine animals and testing of exhaled airflow detect the early signs of an URT infection. The identification of etiologic agent is crucial to set up efficient treatment regimen based on selection of proper antibiotics or other antimicrobials. The results of the studies on the Black Sea marine mammal's respiratory microflora conducted in the Batumi dolphinarium during 2012- 2017 have been analysed in parallel with the results of the monitoring of water microbial quality in the dolphinarium's pool. It was shown that the URT microflora of healthy dolphins was considerably low in numbers (10- 200 cells per sample) but quite diverse. In animals with disease symptoms URT samples yielded > 1000 cells with reduced species diversity. No correlation of the water microbial data with the results of bacteriological investigation of the exhaled air was shown. The URT microflora of dolphins in Batumi dolphinarium was represented mainlly by Staphylococcus spp., Pseudomonas spp. and other non-fermenting G-bacilli, enterobacteria etc. Majority of these bacteria are considered as opportunistic pathogens capable to cause respiratory disease in the animals with weakened immune system. Among the bacterial isolates collected during 3 described cases of dolphin's sickness in 2012 the species with high pathogenic potential for dolphins - Aeromonas salmonicida, Erysipelotrix ruthiopathie and Shewanella putrifaciens were presumptively identified along with opportunistic bacteria - $S$. aureus, S. epidermidis and Corynebacterium spp. 


\section{Introduction:-}

The respiratory system of sea mammals is a high risk area in terms of colonization with pathogenic bacteria. The dolphins in the wildlife habitats often experience the respiratory diseases such as pneumonia, abscess etc, predominantly caused by Gram-positive cocci, mainly by $S$. aureus, and also some gran-negative bacilli, such as $P$. aeruginosa. Staphylococcal bacterial pneumonia was many times reported as a cause of the death of stranding dolphins (Kinoshita et al., 1994). In addition, monitoring done on dolphins in noogenic conditions revealed also a high death rate related to $S$. aureus bacterial pneumonia while fatal cases caused by gram-bacteria were less frequently reported ( Sweeny and Ridgway, 1975; Tserodze et al., 1982; Tserodze et al., 2018).

The vulnerability of the respiratory system of cetaceans is believed to be linked with the evolutionary respiratory adaptations evolved to consist with the prolonged breath holding during deep dives followed by short, rapid expirations and inhalations ( Piscitelli et al., 2013) These respiratory patterns, coupled with a direct conduit from the blowhole to lungs, may facilitate inadvertent aspiration of small quantities of the neuston- the most hydrophobic sea surface microlayer (SML) which is enriched in dissolved organic matter, lipids and microbiota(Cunliffe M, et al. , 2012; . Lisset al., 2016, Zhang et al., 2003) During porpoising, aerosolized SML laden with microorganisms and contaminants may be aspirated deep into the tracheobronchial tree and deposited into alveolar spaces with more forceful exhalation and inhalation respirations. Impaired host immune status related to contaminant loads, reproductive and other stressors may contribute to deeper tissue invasion and proliferation of commensal bacteria resulting in a respiratory disease (Raverty et al., 2017). Although living condition for captive marine mammals significantly differ from wildlife conditions, we can assume some similar mechanism in noogenic conditions which can resemble the above mentioned links between SML and the respiratory diseases in animals. In fact, diseases of infectious etiology of the upper respiratory tract (URT) represent serious problem for marine mammals adapted to noogenic conditions. The changes in climatic conditions, nutrition and stress of animals living in artificial environment can result in bacterial overgrowth and disease development with possible spread in the community. An anthropogenic contamination of pool water is believed to be main source of potentially harmful bacteria . The assessment of the composition of microorganisms within both exhaled breath samples and the water pool could reveal a potential relationship between host respiratory and environmental microbial flora. Treatment of already advanced disease is complicated and positive outcome largely depends on timely diagnostics. Regular control of behavioral and nutritional changes of marine animals, examination of general health status parameters (e.g. blood analysis) and testing of exhaled air allow detect the early signs of an URT infection (Andreeva et al., 2004; Denisenko, 2008).

In addition, identification of etiologic agent(s) of infectious disease(s) in marine mammals is crucial to set up efficient treatment regimen based on selection of proper antibiotics or other antimicrobials.

The presented study aimed to estimate the respiratory microflora or marine mammals - inhabitants of the Batumi dolphinarium and to evaluate its relationship with environmental factors, predominantly the dolphin's pool water quality, also to isolate and identify the bacteria - etiologic agents in relation to some sickness episodes of marine mammals. In our earlier publication ( Tserodze et al, 2016) we reported on the results of 34 months surveillance (2012-2014) of the water hydrochemical and microbiological quality in marine mammals's habitat in Batumi dolphinarium. Here we present the water quality testing results for the next period (2015-2017) in parallel with the analysis of the study of microflora in the dolphin's exhaled air during 2012-2017.

\section{Materials and methods:-}

Marine mammals:-

eighteen (18) adult bottlenose dolphins represented by 7 individuals of Tursiops truncatus gilli ( Pacific bottlenose dolphin) and 9 individuals of Tursiops truncatus ponticus ( Black Sea bottlenose dolphins), 2 dolphins of the letter group were born in Batumi dolphinarium

Physical-chemical parameters;-

Of pool water, such as water temperature, $\mathrm{pH}$, salinity, oxidation-reduction potential (ORP) were measured as described earlier ( Tserodze et al, 2016). 


\section{Microbiological parameters of water quality:-}

Total (viable) Bacterial Counts ( TBC) at $36^{\circ}$ and at $22^{\circ} \mathrm{C}$ were determined by pour plate technique; Total coliform counts (TCC); E. coli, total enterococci ( ENT), numbers of S. aureus and P. aeruginosa were estimated by membrane filtration methodology; for some microbiological parameters, including yeast \&mold number, Rida Count tests (R-Biopharm AG, Germany) and Compact Dry Tests (R-Biopharm AG, Germany) were used as well.

\section{Collection and processing of respiratory samples:-}

The samples of exhaled air from marine mammals were obtained after preparation procedures of dolphins. Animals were previously trained to exhale air at command. Air sample were collected at the moment of breathing by applying over the blowhole a sterile petri dish filled with the Tryptic Soy agar $+5 \%$ sheep blood ( TSAB), and Sabouraud agar+chloramphenicol ( Fig.1). The immediately covered petri dishes incubated during 24 hours at $37^{\circ} \mathrm{C}$ ( for TSAB plates) and at $25^{\circ} \mathrm{C}$ 5-7 days (for Sabouraud plates ) and the number of developed colonies were counted ( fig. 2). For detection of hemolysis the incubation was prolonged for up to $48 \mathrm{hr}$ and the colonies also were categorized as Hem+ or Hem-.

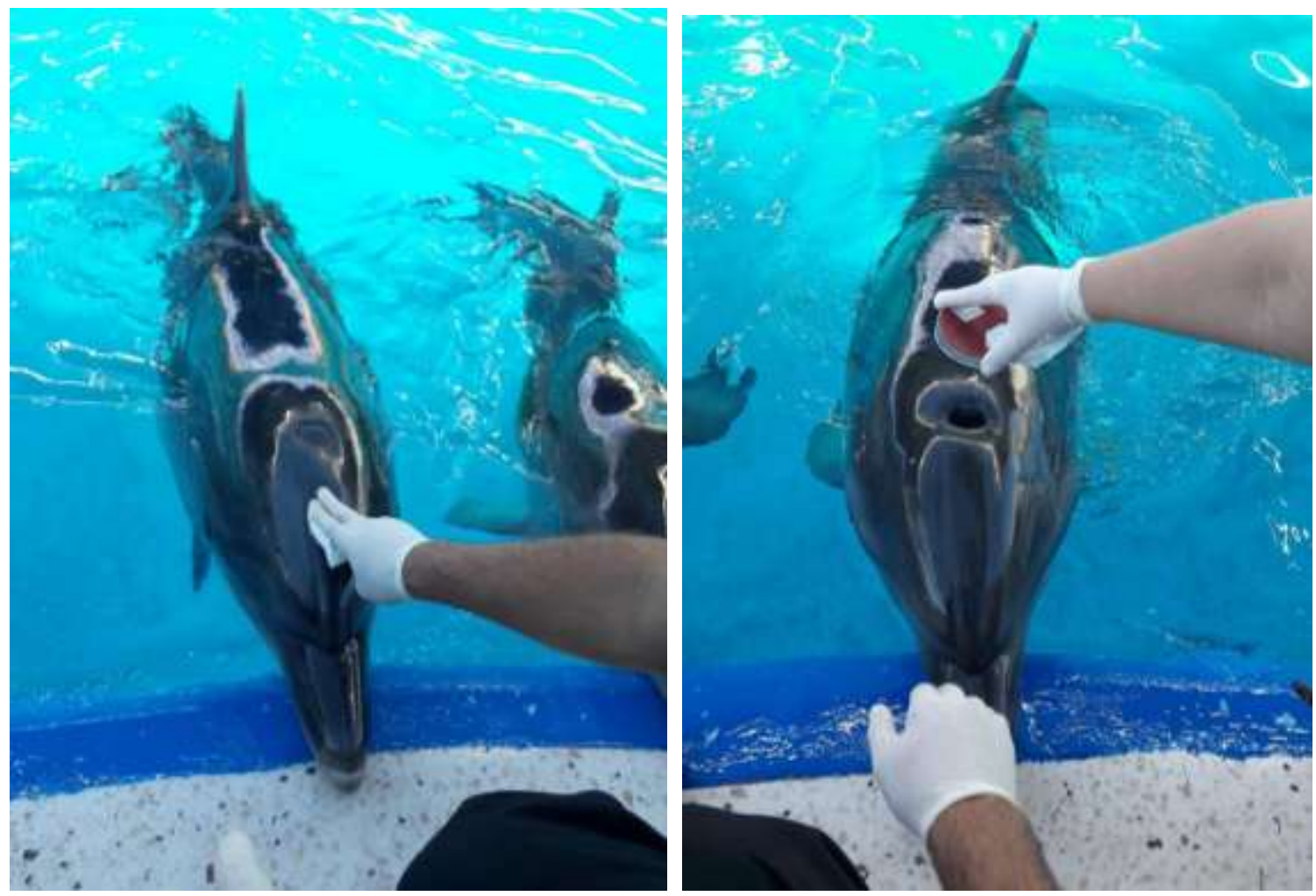

Figure. 1:- Collection of respiratory samples for bacteriological investigation

For identification of selected isolates conventional Gram staining and microscopy, as well as several basic biochemical tests were performed: $\mathrm{KOH}$, Citochrom oxidase, catalase, amino acid utilization and carbohydrate fermentation tests. Also API 20E, API 20NE and APIStaph test systems ( Biomereux, France) were used.

The susceptibility of bacterial isolates to antibiotics and sulfonamids was determined by Kirby - Bauer disc diffusion method (Bauer et al, 1966). The zones of inhibition were measured and interpreted according to international standards (Hudzicki, 2009).

The susceptibility of bacterial strains to bacteriophages were studied by phage sport test on the lines or lawns of bacterial strains on solid media. The different lytic reactions ( cl, scl, IP) were registered.

Statistical analyses were carried out using the Statistical Toolpak for Microsoft Excel 2015. All correlations (Pearson's r) listed herein are significant at the 0.05 level. 

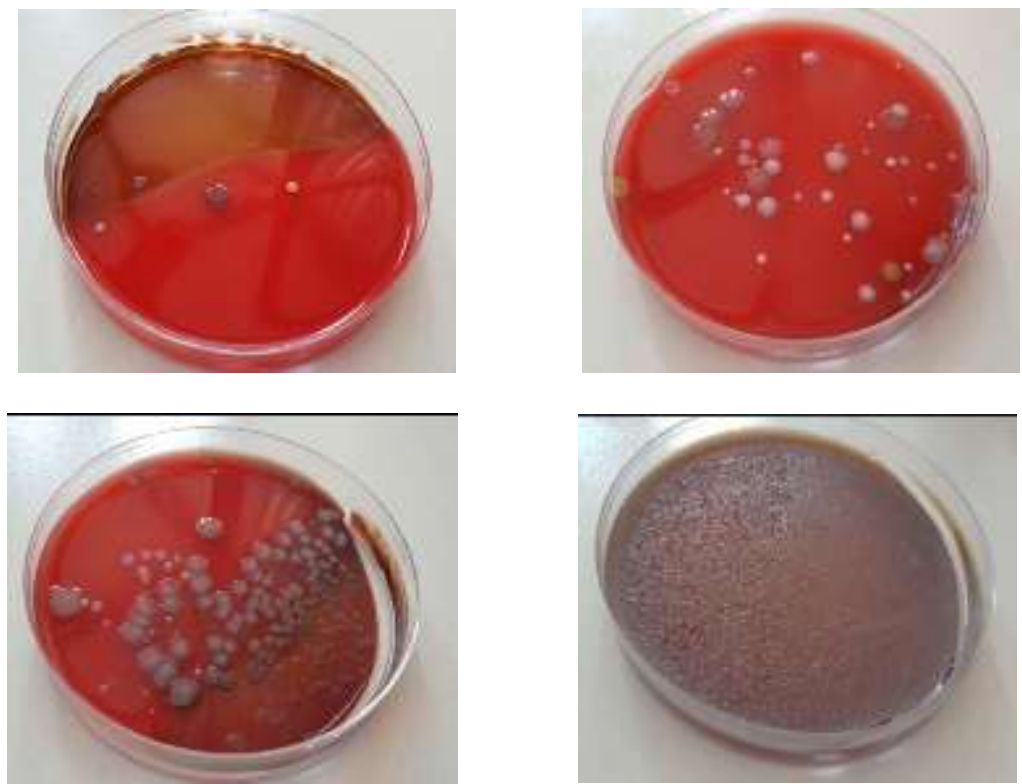

Figure.2:- Bacteriological investigation of exhaled air samples demonstrating different grades of bacterial growth on TSAB plates : a) $<10 \mathrm{CFU}$; b) 10-100 CFU/; c) >100 CFU; d) >1000 CFU

\section{Results and discussion:-}

The water microbial quality in the marine mammals'a pool in Batumi dolphinarium has been studied during 20122017. The data about first 2 years (2012-2014) have been reported earlier ( Tserodze et al, 2016). The next 3 years data have been obtained and analysis was done as for previous years. It appeared that the water microbial parameters were changing showing certain seasonal character (Fig.4), that can be linked to a natural variation of water temperature. This particularly applies to the elevated temperature in summer and early autumn period when increase in values of water pollution indicators can reflect increased anthropogenic impact in summer time. The episodes of worsening on microbial quality during cold season especially after rainy periods, may reflect external microbial load due to water precipitation. Also, again as in the previous period ( 2012-2014) in few cases considerably low microbial quality can be explained by failure in the pool water management system.

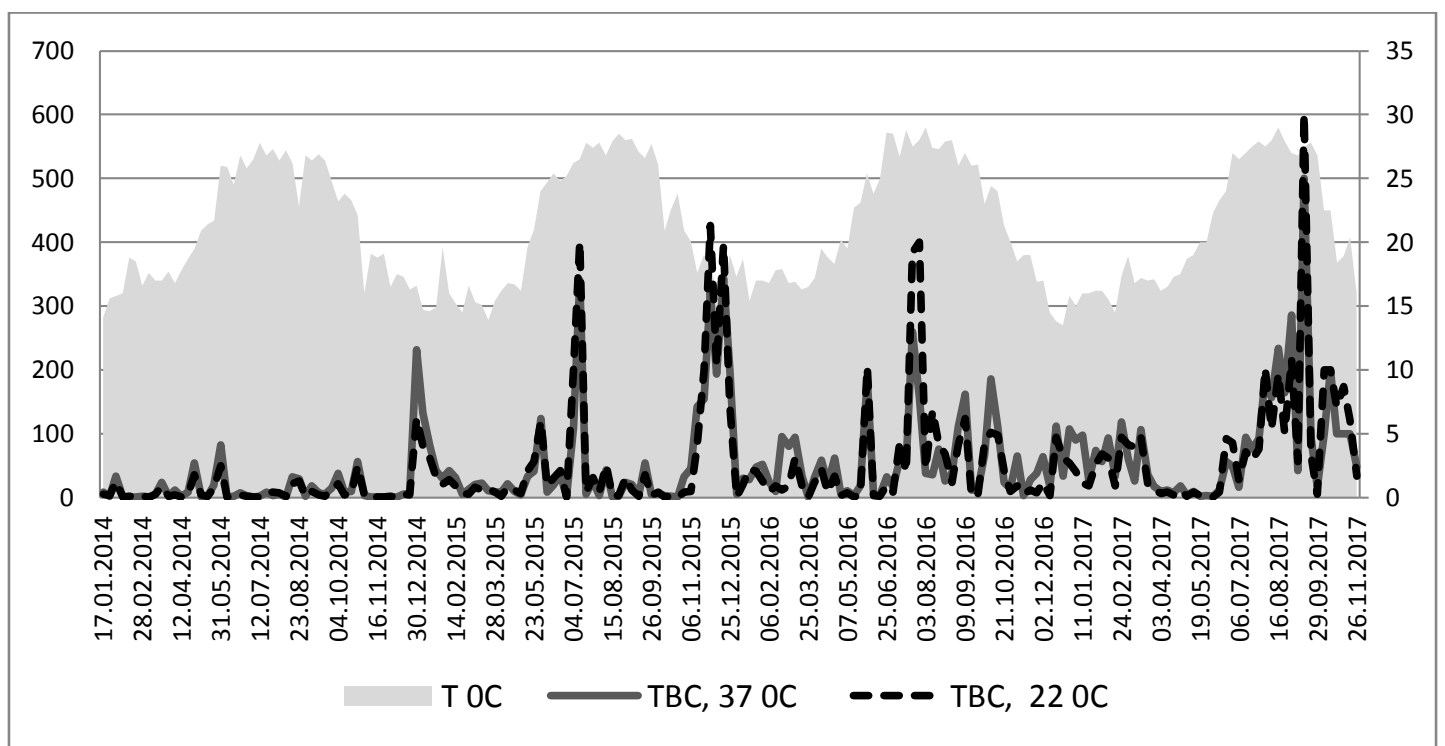

Figure 4:- Seasonal fluctuation of water microbial parameters $\left(\mathrm{TBC} 37^{\circ} \mathrm{C}\right.$; $\mathrm{TBC} 22^{\circ} \mathrm{C}$ ) in the pools of the Batumi dolphinarium in 2014-2017: 
In total, the six year monitoring conducted in Batumi dolphinarium demonstrated the considerable stability of the pool water physical- chemical and microbiological parameters which were mainly varying within the permissible ranges (Fig 4.).

The positive correlations have been found between the majority of the water microbial parameters (Table 1 ). The numbers of potential pathogenic bacteria, such as $S$. aureus and $P$. aeruginosa have been linked to fecal indicators and total bacterial counts. But, unlike $S$. aureus no positive correlation has been found between $P$. aeruginosa and enterococci counts, probably due to more hardiness of enterococci in the marine waters. Also, P. aeruginosa count has been the only parameter that showed the temperature dependence. As expected, the significant correlation (Table 2) was registered between the numbers of fecal indicators (total coliforms, E.coli and enterococci), and also between TBC (Total bacterial count) and all other water microbial parameters (Table 1). Some water microbial parameters, such as total coliforms showed negative correlation with free chlorine content $(\mathrm{r}=-0.26$ and $\mathrm{r}=-0.27$ respectively). The higher negative correlation between $\mathrm{ORP}$ and total bacterial counts at $37^{\circ} \mathrm{C}(\mathrm{r}=-0,2)$ and total coliforms ( $\mathrm{r}=-0,26)$ should be underlined.

Table 1:- Correlation between different water microbial parameters in 2014-2017 years. Correlation is considered positive if $r>0,26$, sample size $n=45$.

\begin{tabular}{|l|l|l|l|l|l|l|l|}
\hline Parameter & $\begin{array}{l}\text { T.M. } \\
\mathrm{C} \\
37^{\circ} \mathrm{C}\end{array}$ & $\begin{array}{l}\text { T.M. } \\
\mathrm{C} \\
22^{\circ} \mathrm{C}\end{array}$ & $\begin{array}{l}\text { Total } \\
\text { coliform } \\
\mathrm{s} / \\
100 \mathrm{~mL}\end{array}$ & $\begin{array}{l}\text { E.coli/100 } \\
\mathrm{ml}\end{array}$ & $\begin{array}{l}\text { Enterococcs/10 } \\
\text { 0ml }\end{array}$ & $\begin{array}{l}\text { Ps.aeruginosa/10 } \\
\text { 0ml }\end{array}$ & $\begin{array}{l}\text { St.aureus/10 } \\
0 \mathrm{ml}\end{array}$ \\
\hline T.M.C $37^{\circ} \mathrm{C}$ & 1,00 & & & & & & \\
\hline T.M.C 22 ${ }^{\circ} \mathrm{C}$ & 0,91 & 1,00 & & & & & \\
\hline $\begin{array}{l}\text { Total coliforms/ } \\
100 \mathrm{~mL}\end{array}$ & 0,80 & 0,67 & 1,00 & & & & \\
\hline E.coli/100ml & 0,64 & 0,68 & 0,54 & 1,00 & & & \\
\hline Enterococcs/100ml & 0,41 & 0,32 & 0,26 & 0,28 & 1,00 & & \\
\hline $\begin{array}{l}\text { Ps.aeruginosa/100 } \\
\text { ml }\end{array}$ & 0,26 & 0,38 & 0,30 & 0,32 & 0,19 & 1,00 & \\
\hline St.aureus/100ml & 0,43 & 0,51 & 0,39 & 0,57 & 0,34 & 0,60 & 1,00 \\
\hline
\end{tabular}

The studies on the Black Sea marine mammal's respiratory microflora have been done in 2012-2017 in Batumi dolphinarium with up to 1200 testings in total. During the six year observation period in Batumi dolphinarium the respiratory samples were collected from up to 18 adult animals in total. The number of samples was ranging from 253 (in 2014) to 164 ( in 2017) (Table 2). The variation is sample numbers were mainly related to the necessity of multiple samplings in certain periods because of warning health status of individual dolphins. The extensive laboratory investigations have been done including hematological, biochemical and bacteriological analysis of blood and respiratory samples collected from the dolphins. The samples of exhaled air were collected from the sick dolphins, were subjected to detailed bacteriology investigations with isolation and identification of potential pathogen. The obtained microbial isolates were characterized by morpho-physiological and biochemical properties and were phenotypically identified.

Table 2:- The quantitative and qualitative data of dolphins exhaled air samples for the period of 2012-2017.

\begin{tabular}{|c|c|c|c|c|c|c|c|c|}
\hline \multirow[t]{2}{*}{ Years } & \multirow{2}{*}{$\begin{array}{l}\text { Number } \\
\text { of } \\
\text { Exhaled } \\
\text { Air } \\
\text { samples }\end{array}$} & \multicolumn{4}{|c|}{$\begin{array}{l}\text { Number of exhaled air samples with } \\
\text { different values of TBC }\end{array}$} & \multirow{2}{*}{$\begin{array}{l}\text { Number } \\
\text { of } \\
\text { samples } \\
\text { containing } \\
\text { hem+ } \\
\text { colonies }\end{array}$} & \multirow{2}{*}{$\begin{array}{l}\text { Number } \\
\text { of } \\
\text { samples } \\
\text { containing } \\
\mathrm{G}^{+} \\
\text {Bacteria }\end{array}$} & \multirow[t]{2}{*}{$\begin{array}{l}\text { Number of samples containing } \\
\mathrm{G}^{-} \text {Bacteria }\end{array}$} \\
\hline & & TNTC & $>1000$ & $<1000$ & $\leq 10$ & & & \\
\hline 2012 & 225 & 23 & 72 & 99 & 23 & 60 & 151 & 143 \\
\hline 2013 & 213 & 13 & 83 & 100 & 17 & 55 & 113 & 129 \\
\hline 2014 & 253 & 67 & 82 & 88 & 16 & 51 & 167 & 120 \\
\hline 2015 & 184 & 55 & 65 & 37 & 27 & 42 & 129 & 60 \\
\hline 2016 & 185 & 38 & 75 & 43 & 29 & 38 & 105 & 70 \\
\hline
\end{tabular}




\begin{tabular}{|l|l|l|l|l|l|l|l|l|}
\hline 2017 & 164 & 51 & 63 & 20 & 30 & 15 & 41 & 24 \\
\hline
\end{tabular}

Depending on our observations the excessive number of microorganisms in dolphin's exhaled air samples was mainly registered in the winter and autumn seasons for all monitored years when the water temperature in the water pool was relatively low and the water microbial parameters in general were in range of acceptable levels. Interestingly, the elevated number of samples with microbial counts below permissible levels prevailed for summer seasons, mostly for June, July and August( Fig. 3, 4) when TBC and water microbial pollution indicators were relatively above admissible norms.

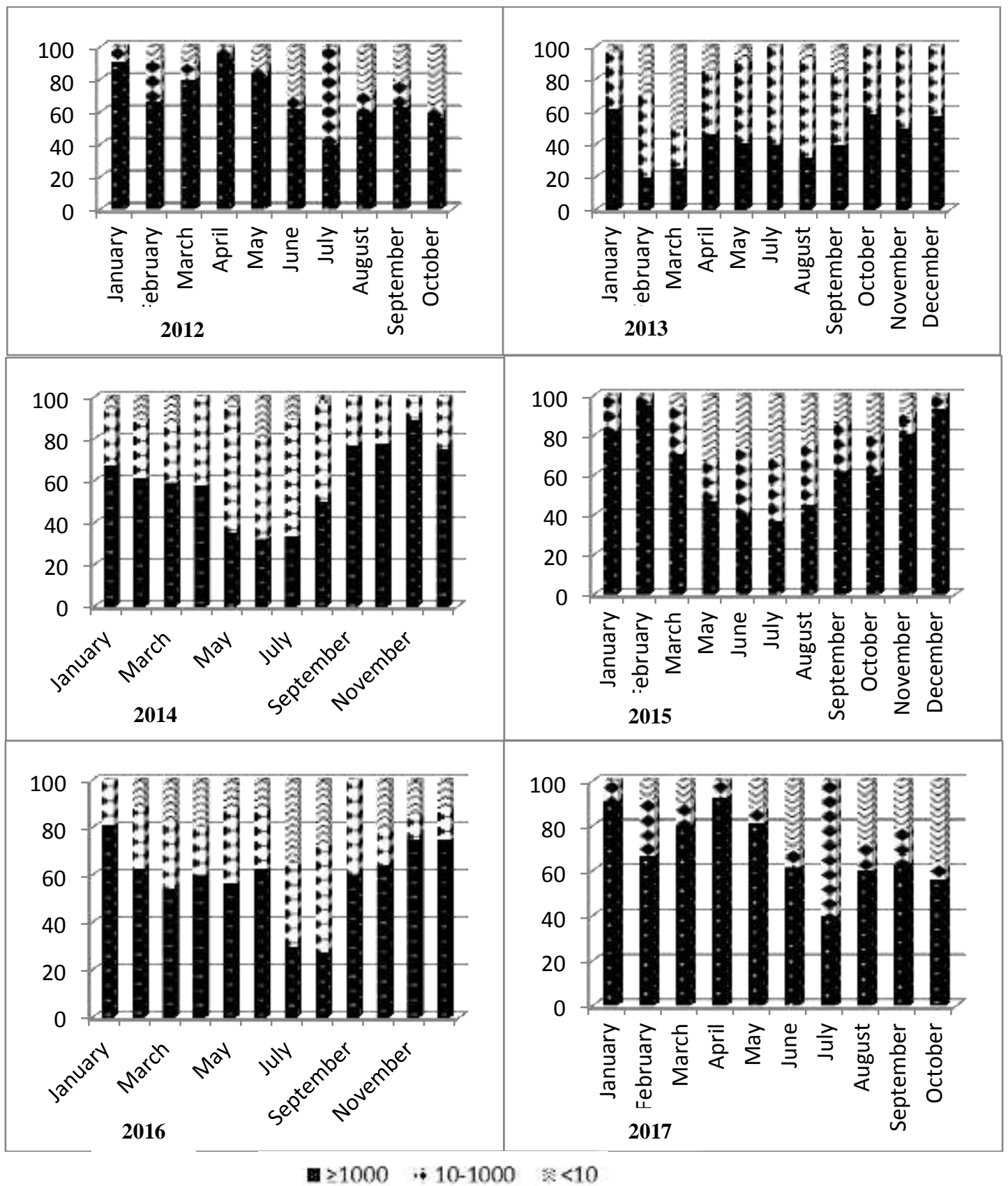

Figure 3:- Distribution of exhaled air samples with different microbial loads by months each observational year during 2012- 2017 
The URT microflora was represented by Staphylococcus spp., Pseudomonas spp. and other non-fermenting Gbacilli, enterobacteria, aeromonads, streptococci, yeasts, actinomycetes etc. Majority of these bacteria are considered as opportunistic pathogens capable to cause respiratory disease in the animals with weakened immune system.

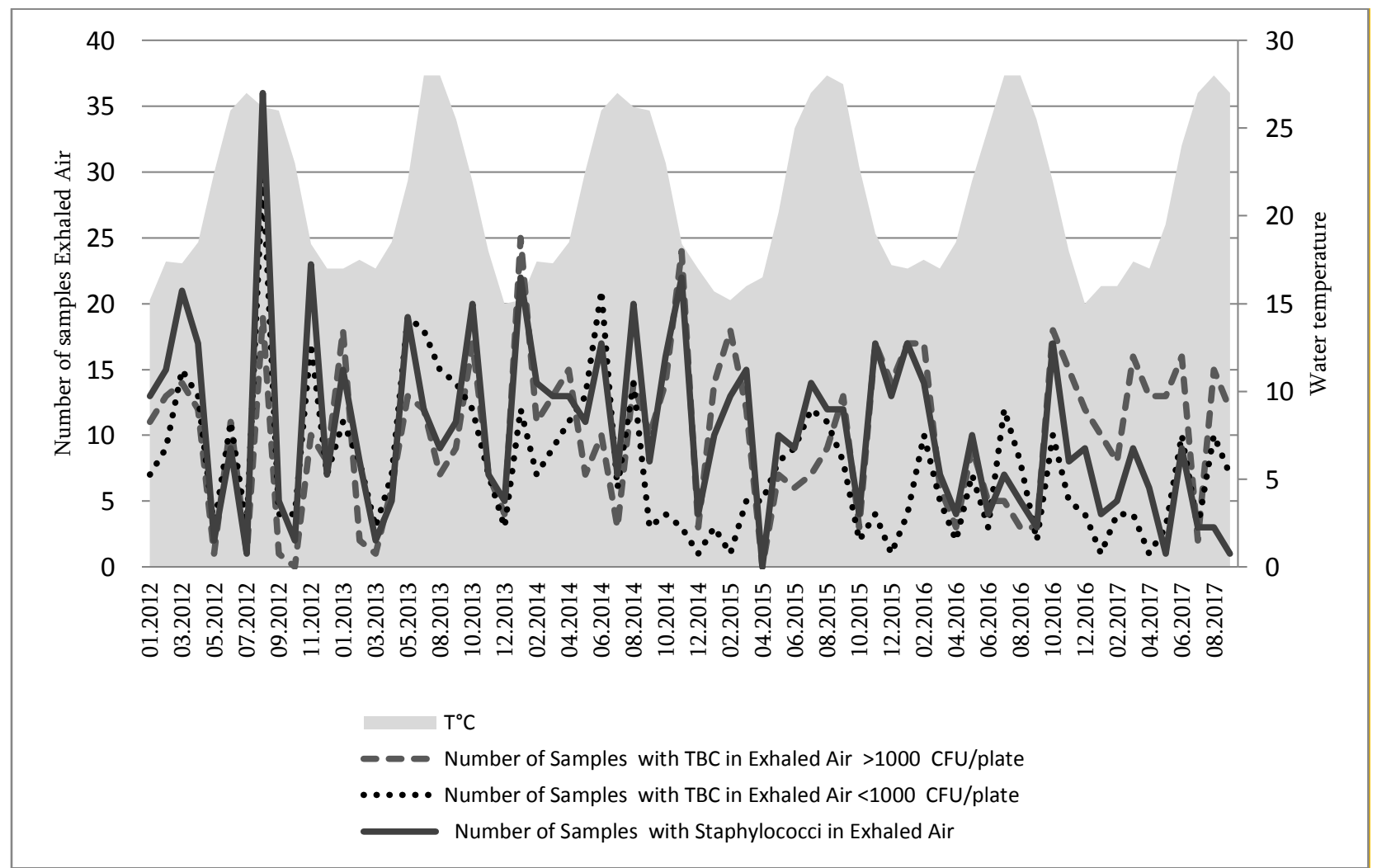

Figure 4:- Distribution of exhaled air samples with different microbial loads in relationship with water temperature in dolphins pools during 2012- 2017

Correlations between water physical-chemical, microbial parameters and bacterial numbers in dolphins' exhaled air have been estimated. High correlation $(r=0,69$. ) has been found between numbers of exhaled samples containing staphylococci and the total bacteria exceeding the accepted level. Negative correlation has been observed between the numbers of exhaled samples with high total bacteria content, temperature and ORP ( $r=-0,36 ; r=-0,32$, respectively). Interestingly, no correlation has been found between numbers of dolphins' exhaled air samples with increased numbers of bacteria and water microbial parameters, that may indicate possibly less significant influence of water microbial pollution on the respiratory flora of captive dolphins, which is also confirmed by some studies (Bik et al.,2017). This observation may lead to assumption that probably at lower temperatures the dolphins' host defense mechanisms are less effective and not enough to limit the colonization and overgrowth of bacteria in the respiratory tract due to more stressful conditions in cold months. The attack of bacteria on the dolphin organism in winter becomes more massive, which can cause an increase in disease incidence in animals (Kuznetsov, 2006). Interestingly, the number of the exhaled air samples containing staphylococci correlated $(r=0,301)$ with free chlorine content. We assume that the chlorine treatment could eliminate majority of chlorine sensitive bacteria in the respiratory tract, while the growth of more resistant, gram positive bacteria, such as staphylococci (can be somehow enhanced (Engelbrecht et al., 1974).

In addition to the summarized results showing the overall microbiological profiles of the respiratory system and its possible relationship with the water quality parameters, here we present the results of microbiological investigations for some disease cases of marine mammals in Batumi dolphinarium. In winter of 2012 the disease signs were observed in three dolphins and corresponding microbiological investigation were carried out in parallel with hematological analysis and blood biochemistry, in particular, leukocytosis and some elevated biochemical parameters (data not shown here) that indicated possible infections in marine animals. 
In total 19 bacterial isolates have been collected during these 3 disease cases. Eight of them, Gram-positive bacterial isolates were identified as S.epidermidis (3 isolates) and S. aureus(2) and 2 Corynebacterium spp.( 2). Three isolates with similar- morpho- biochemical properties were presumptively attributed to Erisypellothryx ruthiopathie, assuming that if so, the strains produce some atypical traits. The API20NE identification of Gram oxidase positive isolates resulted in Shewanella (former Pseudomonas) putrifaciens for three strains with similar characteristics and one isolate was attributed to Aeromonas salmonicida. Among these bacterial isolates obtained from animals with disease symptoms, A. salmonicida, E.ruthiopathie, Sh. Putrifaciens are known pathogens of aquatic vertebrate animals, while the rest are opportunistic bacteria.

The susceptibility of bacterial isolates to 24 antibiotics was studied by Kirby-Bauer's Disc diffusion methods. Part of dolphin's URT isolates appeared to be multidrug resistant, with total resistance to sulphonamides and majority of commonly used cephalosporines, including their combinations with betalactamease inhibitors. Fluoroquinolones, aminoglycosides and chloramphenicol showed considerably high antibacterial activity ( >60\%) (fig.5).

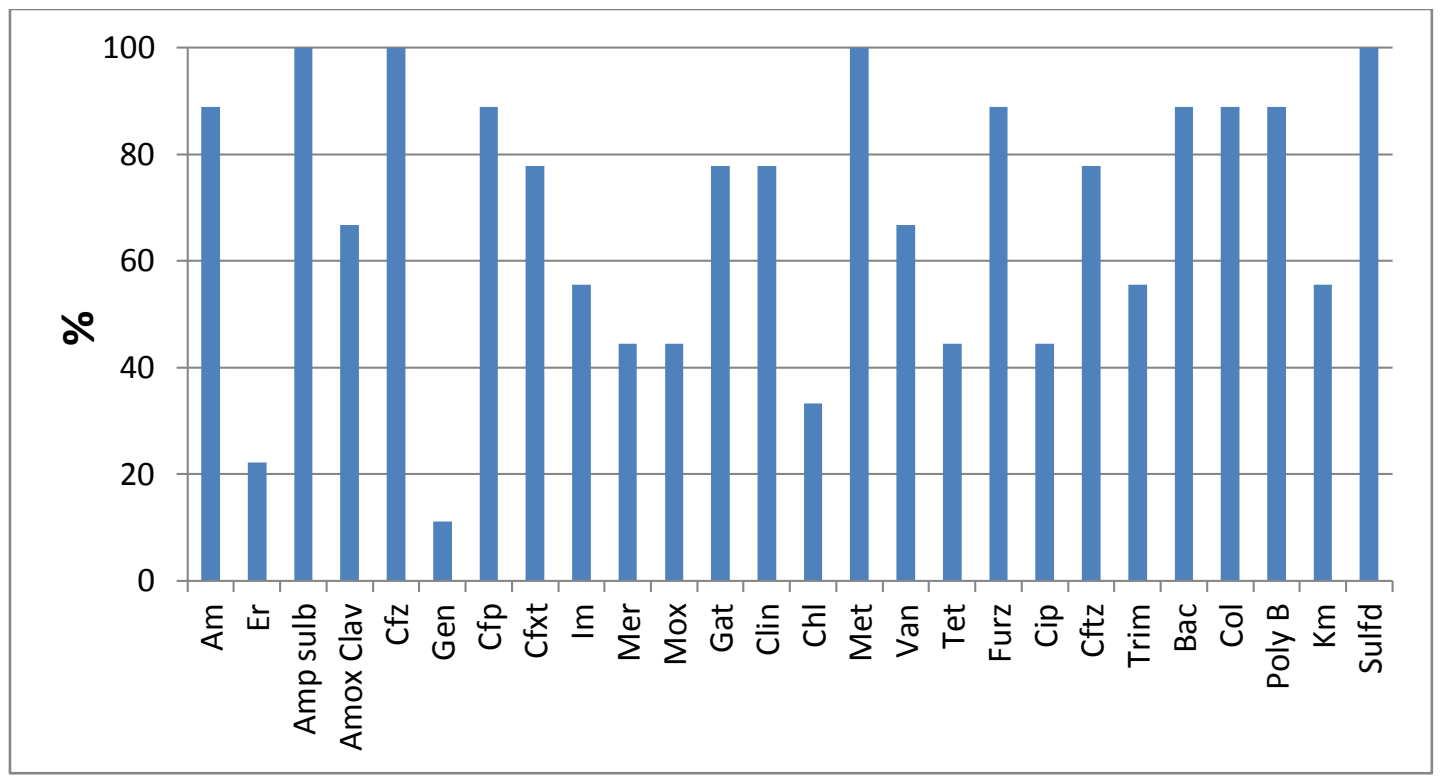

Figure.5:-Antibiotic resistance rates among bacterial isolates collected from dolphins in Batumi dolpinarium

The same set of bacterial strains ( 90 isolates) were screened by phage spot test to determine susceptibility of part of the isolates ( S. aureus, P. aeruginosa, K. pneumoniae, Enterococcus spp, E.coli, A. salmonicida, A. hydrophila ) to 6 commercial phages ("Eliava Biopreparations') and 12 individual phages, active to above mentioned bacterial species, from the Eliava lab collections. The conducted work showed variable susceptibility of bacterial strains ( details not shown here). Based on the amount of isolates lysed least one of the tested phages the highest susceptibility ( $>80 \%$ ) was shown for $S$. aureus, considerably less for $P$. aeruginosa and Enterobacteriaceae (E.coli and Klebsiella) -more then $60 \%$ and Enterococcus spp )- 41,5\%. The broader lytic spectrum of individual phages in comparison with the commercial phage preparations was shown. The studies demonstrated the future perspective of phage application for elimination of bacterial infections in the noogenic habitats of marine mammals, especially for bacteria with high intrinsic antimicrobial resistance. 


\section{References:-}

1. Andreeva N.A., Smirnova L.L., Ostapchyuk A.V., Microbiological health aspects of the Black Sea bottlenose dolphins (Tursiops truncates) in the coastal marine enclosure. Marine mammals of the Holarctic, pp.29-31, 2004.

2. Bauer, A.W., Kirby, W.M.M., Sherris, J.C. and Turck, M. (1966) Antibiotic susceptibility testing by a standardized single disk method. Am J Clin Pathol 45: 493-496.

3. Bik E. M., E. K. Costello, A. D. Switzer, B. J. Callahan, S. P. Holmes, R. S. Wells, K. P. Carlin, Eric D. Jensen, S. Venn-Watson \& D. A. Relman. Marine mammals harbor unique microbiotas shaped by and yet distinct from the sea. Nature Communications, DOI: 10.1038/ncomms10516, www.nature.com/ naturecommunications , 2015.

4. Cunliffe M, et al. Sea surface microlayers: A unified physicochemical and biological perspective of the airocean interface. Prog.Oceanogr. 109:104-116. 2013.

5. Denisenko T.E. Microflora of white whale (Delphinapterus leucas) upper respiratpry tract. Marine mammals of the Holarctic, pp.184-186, 2004.

6. Engelbrecht S. R.,. Foster D.H, Greening E.O.,Lee S.H., New microbial indicators of wastewater chlorination efficiency, United States. Environmental Protection Agency. Office of Research and Development, Environmental Protection Series, Volume 1, ERA-670/2-72-0,82; 1974.

7. Hudzicki Jan. Kirby-Bauer Disk Diffusion Susceptibility Test Protocol, American Society for Microbiology, 23 p., 2009.

8. Kinoshita R., Brook, F., Vedros, N., Wad, H.S., Lung, R., Ng, T., Tao, L.Y., and Yuen, C.S., Staphylococcal isolations and clinical cases of Staphylococcus aureus in bottlenose dolphins at Ocean Park, Hong Kong, in Proceedings of the 25th Annual Workshop of the International Association for Aquatic Animal Medicine, 159, 1994.

9. Kuznetsov V.B. Presence of water in the upper respiratory ways the main reason of infectious sidease of marine mammals Marine mammals of the Holarctic, pp.296-298, 2006.,

10. Liss P.S. and Duce R.A. The sea surface and global change. (Cambridge University Press, 1997). 2016. $\quad$ https://www.cambridge.org/core/books/the-sea-surface-and-global-change/B08F5A777C24973 C40A458A7AECAC3F7.

11. Piscitelli MA, Raverty SA, Lillie MA, Shadwick RE. A review of cetacean lung morphology and mechanics. J. Morphol. 274:1425-1440, 2013.

12. RavertyS.A., Linda D.R., ZabekE., EshghiA., CameronC.E., Hanson B.M. \& SchroederJ.P., Respiratory Microbiome of Endangered Southern Resident Killer Whales and Microbiota of Surrounding Sea Surface Microlayer in the Eastern North Pacific, Scientific Reports 7, Article number: 394, doi:10.1038/s41598-01700457-5, 2017.

13. Sweeney J.C.., and Ridgway S.H., Common diseases of small cetaceans, J.Am.Vet.Med.Assoc., 167(7), 533$540,1975$.

14. Tserodze T., Bolkvadze Z., Djincharadze K., Staphylococcal infections in early ontogeny of dolphins. Study, protection and rational use of marine mammals: 8 All-Union Conference, Astrakhan, October 5-8. 1982: Thesesof the reports, Astrakhan, pp.399-400. 1982.

15. Tserodze T., N. Zobova, D. Jgenti, M. Mgeladze, R. Goradze, E.Jaiani,E. Didebulidze, and M. Tediashvili. Study of water hydrochemical and microbiological quality in the noogenic habitat of the Black Sea bottlenose dolphins. Int. J. Adv. Res. 4(9): 2063 - 2067, 2016.

16. Tserodze T., D. Jgenti , M. Mgeladze , N. Chkheidze , R. Lomidze , I. Gambashidze , N. Janelidze , E. Didebulidze, A. Groene, M. Kik and M. Tediashvili . Fatal bacterial infection of the heart in captive dolphin (Tursiops truncates golli). A case study, Int. J. Adv. Res. 6(1): 795-804, 2018.

17. Zhang Z.B, Liu L.S, Liu C.Y, Cai W.J. Studies on the sea surface microlayer - II. The layer of sudden change of physical and chemical properties. J. Colloid Interface Sci. ;264:148-159, 2003. 